\title{
THE IMPLICATIONS AND PURPOSE OF USING INTERNATIONAL PHONETIC SYMBOLS AND ENGLISH ADVERTISING SLOGANS IN ADVERTISEMENTS IN POLAND
}

\author{
HANNA DZICZEK-KARLIKOWSKA
}

\begin{abstract}
This paper examines the various implications resulting from the use of English phonetic transcription in advertising in Poland. I focus on the problem of the use of phonetic transcription by copywriters as a graphic form and I make an attempt at showing that this technique can have pedagogical consequences, because a graphic form in which phonetic symbols are used is, in fact, a text message, not an image only. In addition, I analyze selected advertisements as a means of communication addressed to a specific recipient. In this case, I demonstrate that the use of advertising slogans in English and English phonetic transcription in Poland, does not guarantee that such advertising is effective.
\end{abstract}

Key words: phonetic transcription, English in advertising, phonetics and phonology linguistics, advertising

\section{Introduction}

This article is aimed at examining the implications of introducing to the Polish market the advertising technique in which the advertising agency speaks to the potential customer through the use of phonetic symbols drawn from the International Phonetic Alphabet (Jones 2006). In this paper, by analyzing the facts published on the website Szczecin.wyborcza.pl and the results of my own research, I am searching for the purpose and legitimacy of launching this type of advertising examining the problem from the pedagogical and sociolinguistic point of view.

For the purposes of this research, the advertisement of the city of Szczecin is used, namely, „Szczecin - Floating Garden Project 2050”, in which there is a logo 
built on the basis of the phonetic transcription of the city's name, that is, [ $f \mathrm{f}$ e't fin] and a slogan in English, and, additionally, the phonetic transcription of the word amazing, i.e. [э'meIzIn] instead of [ə'meIzIn], placed in the advertisement launched by Škoda, namely, “Zobacz co znaczy amazing. Amazing [э'meızın] to znaczy Nowa ŠKODA Octavia" (https://www.google.pl/search?q=Škoda).

While the idea for an advertisement using a slogan in English is no novelty, international phonetic symbols in Polish advertising may arouse interest for many reasons. First of all, it can be assumed that we are having to do with an advertising trick, in which the advertising agency balances on the imagination of the customer who perceives the phonetic transcription as an image. Thus, from the point of view of an advertising agent, the phonetic symbol, one of the basic elements of language, is simply an interesting, eye-catching, less commonly used graphic form.

Secondly, from the point of view of a linguist or a teacher of English, such an exposure to an incorrect record may cause that it will be recognized as correct and as such will be retained in the memory of the recipient who has sufficient knowledge of English phonetics, allowing her/him to recognize the presented record as a phonetic transcription.

Thirdly, it could also be interesting to verify the potential recipient of this type of advertisement. Is she or he English, American, Polish or just a foreigner (e.g. a tourist, a businessman) who speaks English, or a student of English? The posed question answered positively gives rise to the next question, namely, about the recipients' knowledge of phonetic symbols. The same question is true for the rules of phonetic transcription because the Szczecin advertisement in its logo, in addition to the standard symbols found in the English phonetic alphabet, also contains a number of diacritics pointing to phonological processes operating in the pronunciation of this name. In turn, a negative answer may mean that the expected recipient is simply and invariably an average consumer, but without any straightforward indication whether this consumer is a businessman, a tourist, a Pole or a foreigner, whether it is a person who speaks English or not. As hypothesized here, it is uncertain that such advertising will fulfil its goal of appealing to the target audience, as it is not targeted at any specific audience.

The research was conducted in a group of students of English at two private universities in Warsaw. I carried out the surveys in two stages. In October 2017, 163 first-year students were invited to complete the questionnaire who, in most cases, did not demonstrate a well-established knowledge of phonetic symbols or phonetic transcription. In June and July 2018, the research was conducted in the group comprising 79 students who had completed a one or two-semester course in phonetics and phonology of the English language, which allows for an assumption that they had a much broader knowledge in the studied field. In the second stage of the study, in addition to the six basic questions, the students were additionally offered to reflect on the advertisement for a Škoda make. 


\section{Aspects and functions of advertising: literature review}

Advertising has been in the focus of academics since the end of the $19^{\text {th }}$ century. Sampson (1874), for example, looks at advertising from the historical perspective. Scott (1903) and Bovée - Arens (1982) focus on the psychology of consumers to prove that psychology and advertising have to go hand in hand in order for an advertisement to prove successful. Russel (1920) studied advertising from the point of view of marketing and the techniques of successful advertising copy. The first intensive linguistic research in the field was presented by Leech (1966) who describes and evaluates the morphology, semantics and syntax applied in advertisements. However, no mention of phonology has been made.

Also, the communicative and functional values of advertisements found their place in the discussion raised in many academic works. The discussion raised by Vestergaard - Schrøder (1985) was followed by other works by Cook (1992), Myers (1994), Tanaka (1994), Goddard (1998), Hermerén (1999) and others. As for the communicative aspects, Myers and Goddard describe the phenomenon of implementing oral and colloquial components claiming that it was achieved by the use of the pronouns $I$, we and you personifying the public discourse. With regard to the functional value of advertisements, the discussion embarks on their informative and persuasive functions. Tanaka claims that information is subordinated to persuasion, while in Hermerén's opinion, the dominant function of advertisements depends on the type of advertising. In support of this view, he claims that functions differ hence, for example, there is advertising targeted at the consumers or health advertising. When examining advertising, Ewen (1976), Bocock (1993) and Schudson (1993) show it as a kind of a mirror of society and argue that advertising has an influence on the establishment of social values.

Furthermore, Fox (1984 as cited in Gieszinger 2001: 7), notices the role of pictures in advertising claiming that "[...] at the turn of the century illustrations, diverse typefaces and more "literary qualities" were employed instead of the plain style typical of earlier advertisements". The so called pictorial communication in advertising has been in the focus of the recent research carried out, among others, by Vestergaard - Schrøder, Myers, Hermerén and Sauer (1998). As Gieszingier gathers (2001:11), they examine the pictorial presentation of the product and the interrelation between verbal and pictorial information.

Notwithstanding the above mentioned issues, Gieszinger (2001: 14ff) raises the topic of analysing advertisements as a text type. She claims that the concept of text type is particularly important and promising because text types develop gradually in a specific language community. She further argues that "[...] language users are aware of a class of texts called advertisement and often have a fixed attitude towards advertisements. They may regard them as a source of information, as entertaining or as a disturbing factor in their communication process, for example when reading a newspaper or watching television". 


\section{Presentation of the advertisements and official opinions on the use of IPA symbols}

The topic of English words implemented in advertising has been discussed on many levels of the social structure for many years. In many countries, language councils dealing with the purity and correctness of the native language have been created. The Polish institutions, which care for the correctness of the Polish language and the language of advertising, are the Polish Language Council (PLC) and the Committee of Advertising Ethics (CAE). One of the statutory tasks of the PLC is "[...] expressing opinions on the language form of texts intended for public communication, especially in the press, radio and television and in administration" (http://www. rjp.pan.pl/index.php? option $=$ com). In 1999, the activities of the Council were subordinated to the provisions of the Polish Language Act. In connection with the above, the PLC at the request of the inhabitants of Szczecin, reacted to the advertisement of Szczecin, in which apart from the phonetic transcription of the city's name, the advertising slogan in English "Szczecin Floating Garden 2050" was used.

In keeping with the above, let me present the logo at issue and the abridged version of the text promoting the city accompanied by the logo on the official website of the city of Szczecin at http://www.szczecin.eu/en/marka/brand_strategy (original spelling retained).

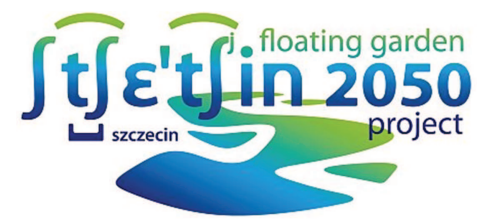

About the symbol of the vision of Szczecin Floating Garden 2050

Szczecin Floating Garden 2050 constitutes the symbol of the city's vision. It is a message to the world, which says that Szczecin is:

- open

- transborder

- innovative

- visionary

- multicultural

- multilingual

Szczecin's goal is to create a unique city - a Floating Garden - by 2050. It is simultaneously a symbol of the city's vision, the name of the project, a promotional logo, and the basis for the whole system of visual identification of this city. This combination escapes the traditionally defined definition of a logo, which is already a point at which Szczecin wants to communicate its uniqueness. 


\section{About language}

The Polish language remains the most important language for Szczecin. However, the symbol of the city's vision is supposed to present the concept of the city and its aspirations not only to Polish people but to the whole world. This is why it has taken such a form. The name of Szczecin is impossible to pronounce for foreigners. Other cities do not have such a problem. But is it really a problem? Paradoxically, it is also a kind of potential, a feature which may be used for promotional purposes of the city. The symbol of the Szczecin Floating garden 2050 project has been inspired by the phonetic transcription of the city's name, using IPA (phonetic pronunciation) symbols. It draws attention to the fact that Szczecin is an open, multicultural city that wants to communicate with the representatives of many languages. Szczecin's ambition is to be perceived as the transfrontier city of the Baltic Sea basin. This is the reason for using the IPA transcription as a graphic element.

In response to the recommendations given by the PLC, on June 25, 2009, the article entitled "The logo promoting Szczecin as a city of floating gardens should be directed only to foreign recipients - the Polish Language Council appeals", appeared on Wyborcza.pl. (http://szczecin.wyborcza.pl/szczecin/). Let us now look at the opinion issued by the PLC on June 25, 2009 in the pages of Wyborcza.pl, which states that "The logo promoting Szczecin as a city of floating gardens should be directed exclusively to foreign recipients". The PLC appealed to the Mayor to change the graphic design for the project to make it consistent with the provisions of the Polish Language Act. The Council explained that under the Act, communications addressed to Poles should be formulated in their native language, and the words "Szczecin - Floating Garden 2050" and the word "project" cannot be considered as written in Polish. The phonetic record of the city's name in international transcription, which indicates the pronunciation of "Szczeczin", was badly assessed. The PLC asked the city authorities to place the name of the city in a central position and to place the corrected phonetic record only as an additional element. Attention was also drawn to the record of the city's name from a small instead of a capital letter, which is a spelling mistake.

As already indicated, the PLC's opinion was published in the pages of Wyborcza.pl. The President of Szczecin responded to it, as can be learned from the publication entitled "Floating Garden for non-Poles", which appeared on June 25, 2009 in Wiadomości Szczecin (http://szczecin.wyborcza.pl/szczecin/1,34,939.6757914). In the same article, we can read that the PLC referred to the President's response in the following way: "The situation is clear now and we have issued a complementary opinion". However, as can be learned from the presented above information retrieved from the current official website of the city of Szczecin and entitled "About the symbol of the vision of Szczecin Floating Garden 2050", the logo contains the questioned phonetic transcription and the slogan in English but they are followed by 
a comprehensive explanation regarding the symbol and language (Polish and English) neatly integrated into the description of the development strategy cities. http://www.szczecin.eu/en/marka/brand_strategy.

Similar to the above described feelings may be aroused by another advertisement, in which Škoda Octavia was advertised on billboards in 2014 in Poland. The advertisement used the slogan “Amazing $\mid \rho$ 'meızıy| Škoda Octavia „(https://www. google.pl/search?q=Škoda). "This advertisement focuses on the different and astonishing definitions / meanings of the English word amazing. The Škoda Octavia astonishes us in the many ways, emotionally and rationally", as was explained by the Communication Manager of a Škoda make. However, this advertisement, despite the well-designed campaign, in the transcription of an English word, used a non-existent symbol in the English language phonetic alphabet, namely [э]. However disquieting it is, this advertising campaign with the wrong phonetic transcription was launched, though. It cannot be ignored, however, that the wrong transcription of amazing, when googled now, is found to be transcribed correctly in the advertisement of Škoda.

\section{The study: aim, data presentation and discussion}

When considering the objective of this paper consisting in the examination of the implications resulting from the use of English phonetic transcription in advertising in Poland, the following issues were analyzed and discussed:

1) Phonetic symbol and phonetic transcription as a graphic form;

2) Teaching pronunciation through errors;

3) Recipient of advertisement with phonetic transcription - communicative advertising function.

As remarked earlier, in the first stage of the survey, 163 students of the first year of English studies at two private universities in Warsaw were invited to participate. Assuming that being students of English studies, they are sensitive to the use of English in various media, including advertising, they were expected to notice the English language on the so-called "foreign ground", i.e. in an environment in which Polish is a native language and to understand and envision the consequences of it. At the same time, the respondents, at the beginning of their education in the field of English studies, were assumed to have only limited knowledge in the subject of phonetic transcription, its correctness and the significance of its incorrectness in didactics. Regardless of the above, they were undoubtedly neutral recipients of advertising able to assess the communicative function of both advertisements with which they were presented.

The survey started with the presentation of the advertisement of Szczecin with a logo containing the phonetic transcription of the city's name and a slogan in English. There were six questions listed and each respondent was asked to choose one answer to each question and, where possible, give their explanation. 
In the first question, the students were asked about the element of the advertisement that draws their attention most. The answer of $57 \%$ of respondents was "the slogan in English" as opposed to the option "English phonetic transcription" - chosen by $17.8 \%$ of them. $25.2 \%$ of participants chose the option "other" explaining, among others, that these were: "year 2050; pleasant colours: white, blue and green; the logo; slogan's being trendy; well-designed graphic form".

In the second question, the participants were asked if they think that the phonetic transcription helps foreigners pronounce the name Szczecin. 56.4\% of them answered "Yes" and, interestingly, one student explained that reading the Polish $<$ sz $>$ and $<\mathrm{cz}>$ letters is difficult for foreigners, so it is good they are given this kind of help. Others (43.6\%) said "No" explaining, for instance, that they doubt that an Englishman knows the phonetic symbols because they themselves do not know the Polish symbols or that if someone wants to know the pronunciation, she/he can look it up in a dictionary where pronunciation is provided in the audio version.

In the third question, they were asked if they, as students of English, benefit from this advertisement in some way. 41.1\% responded "Yes" giving the following explanations: "I can learn transcription; I will know how to transcribe the word Szczecin; I didn't know that Polish words can be transcribed using English phonetic symbols". Others (58.9\% respondents), who responded "No", gave the following explanations: "I know these English words already; I can't read the transcription; I don't know how to pronounce some symbols, for example, [J]".

When inquired about the target recipient of the advertisement, in question number four, $50.3 \%$ of participants responded: "native speakers of English" and 34.9\% answered: "foreign tourists and businessmen". Only $14.8 \%$ of them answered "the Polish recipients".

With regard to the logo and question number five in which the students were asked about its role in promoting the city, $44.2 \%$ of respondents agreed that the logo adequately promotes the city explaining, for example, that "the slogan in English gives more opportunities for the city to attract foreigners; it's catchy because it contains some attractive elements such as phonetic symbols; it shows that the city is modern; nowadays almost everyone who travels knows English, so it's good it is in English. 55.8\% of respondents answered "No" and their explanations were as follows: "not everyone knows English; because of phonetic symbols it is not well understood; I can't pronounce the name of the city with the use of phonetic symbols; it is for foreigners only and should be clear for Poles as well; I wonder if an Englishman knows English transcription and is able to read the name of Szczecin transcribed phonetically".

In the final question of the questionnaire, the students were asked to assess the communicative value of the advertisement using the scale from 1 to 5 , where 5 was the highest positive grade. There were $13.5 \%$ of participants who gave 1 point, 
$10.4 \%$ who gave 2 points, $34.9 \%$ who gave 3 points, $28.2 \%$ who gave 4 and $13 \%$ who gave 5 points.

In the second stage of the study, 79 students, who completed the course of phonetics and phonology, were invited to the survey. Thus, they were respondents who knew the list of phonetic symbols and had a fairly wide knowledge of the rules of phonetic transcription and their practical application in the English pronunciation. Having examined students' answers to the same questions they answered in the first stage of the study, a few of them are worth noting due to their great informative value.

Revisiting the question about the element that draws in this advertisement their attention most, as many as $84.8 \%$ (in the previous stage $17.8 \%$ ) respondents answered "phonetic transcription". The explanations that followed the answers were, for example: "I think transcription is interesting here; I can't pronounce the name of Szczecin as transcribed in this advertisement; strange diacritics are used; the word Szczecin is differently stressed in Polish", etc.

Quite a large discrepancy was also demonstrated in the students' answers to the question "Does the phonetic transcription help foreigners pronounce the name of Szczecin?". The percentage of respondents who gave negative answers was $76 \%$ (previously 43.5\%) and they justified their choices as follows: "No, because there are too many difficult symbols and other signs; I didn't change my opinion, that is, a native speaker of English doesn't know these symbols", etc.

A slight difference in the percentage of positive and negative answers given was observed when the participants were asked the following question: "As a student of English, do you think you can benefit from this advertisement?", 48\% (previously $41.1 \%$ ) of the participants answered "Yes" and 52\% (previously 58.9\%) answered "No".

As with the responses to the question about the target recipient, the students reported no major change in their viewpoint. Similarly, the participants' responses did not change noticeably as to the statement "This logo fulfills the goal of the city", namely, $48 \%$ (previously 44\%) of respondents answered "Yes" and 51.8\% (previously 55, 8\%) answered "No".

In the last part of the questionnaire, the students were asked to refer to the communicative value of the logo using a 5-point scale, the lowest score, or 1 point, was given by $22.8 \%$ of respondents (previously $13.5 \%$ ), and the highest score, or 5 points, was given by $10,1 \%$ (previously $12.9 \%$ ) respondents.

As indicated in the introduction to the article, at this stage of the study, the students were additionally presented with the Škoda brand advertisement with a request to assess its communicative value. The statement "In terms of communicating the car manufacturer's message, this advert can be successful in Poland" was to be assessed with the use of a 5-point scale and the highest rating occurred in $8.5 \%$ of responses, the lowest in $69 \%$ of responses. The respondents supplemented their 
answers with the following justifications: "English words should have been replaced with Polish ones because the advert is shown in Poland; It's OK because it looks international; the ad is more attractive and English words also help learn English; the English word amazing can be difficult to understand for Poles, as it's not commonly used; transcription is incorrect; amazing is transcribed incorrectly - the schwa symbol is non-English; I would change the symbol [ə] to [ə]; using phonetic symbols is trendy now that's why I think the advertisement can be catchy, but one phonetic symbol is not English - [9]", etc.

The data obtained in this research give basis to a number of observations regarding the appropriateness of using the English language and the phonetic transcription of words in advertising. First of all, the use of phonetic symbols planned by the creators of Szczecin's advertising only as a graphic element caused a lot of controversy. Just to remind, the Polish Language Council reacted to the introduction of phonetic symbols, among other things, by negating, firstly, the validity of such an idea, and secondly, the linguistic correctness of the advertising slogan. The Polish Language Council noted the incorrectness of the phonetic transcription of the name of the city of Szczecin indicating an incorrect pronunciation, namely, "Szczeczin". The results of the survey presented above show that for the participants of the study, these issues were of concern as well, as demonstrated by the results to all of the questions presented to them.

Question No.1 was to elicit the respondents' perceptions concerning the advertisement as a whole. As expected, in the first stage of the survey, the majority of respondents reported that it was a slogan in English but $17.8 \%$ of them also noticed the transcription. From the point of view of a copywriter, the goal was fulfilled because the advertisement was meant to address foreigners, to demonstrate that Szczecin is an open, international city and the students' responses seem to prove these assumptions right. Overall, however, based on the students' reflections, it has to be pointed out that the phonetic transcription cannot be treated as a graphic element of an advertisement only, as had been envisioned by the copywriters.

In support of the above assumption, albeit in a very general scope, let us refer to the role of the visual message in advertising. According to Bigaj-Zwonek (in Polak, 2011: 99), "In advertising, there is a concept of visual communication, adequate for imaging in general. It means communicating in a certain way on the basis of certain visual means. These means are the tools by which the image is built". And further, as Szczęsna writes (in Wolny-Zmorzyński and others, 2013: 81), "[...]today, with the help of text supported by a painting, it is possible to more effectively influence the recipient". The results of this study confirm the thesis that the graphic form affects the recipient. However, the participants of this study apart from the graphic form, notice the content in this image, therefore in addition to the visual message, it is also a text message for them. Regrettably, as demonstrated in the reports, this 
message was unfortunate due to linguistic errors. As a result, the errors could be used as a basis for pedagogical intervention.

When responding to question No.5, $41.1 \%$ (first stage) and $48 \%$ (second stage) of students, that is, the minority of them, indicated that they can benefit from the phonetic transcription used in the advertisement. This phenomenon would not be so disquieting if the erroneous transcription was likely to evoke reflection in the recipient and lead to searching for the correct one. The legitimacy of such thinking, however, seems to be overburdened with too many questions. One of them concerns the issue of treating the "advertised" wrong patterns as correct and, in consequence, norm-providing. If no major consequences are observed, as demonstrated in stage one of this research, in defence of linguistic correctness, can the problem be faced with the ethical rules of the profession created for copywriters? The rules preclude such controversial activities, though. The question then arises as to why, regardless of advertising ethics, erroneous pronunciation or transcription is used in advertising. According to Lynch (in Wolny-Zmorzyński and others (2013: 99), "[...] paradoxically, what arouses negative emotions is also interesting and exciting".

Another question relates to the process of teaching and learning from a bad example. The subject of learning the right from the wrong functions in the methodology of teaching foreign languages. For example, Richards and Lockhart (2007) and also Loughran (1996) write about the use of reflection, including reflection on the error, in teaching a foreign language. Also, Dziczek-Karlikowska and Mikołajewska (2015: 172), for the purposes of their research regarding the use of erroneous pronunciation by copywriters for marketing goals in Polish TV commercials, devised a Moodle based course in which they used the incorrect examples from advertisements. They demonstrated that wrong examples "can serve as examples of (in)correct pronunciation of English lexemes and help raise the learners' phonological awareness". The advertisements examined in this paper, however, are focused on an analysis of respondents' reflections when faced with such wrong examples.

To complete the discussion on the errors and their perception by the surveyed students, let us focus on the phonetic transcription used by the creator of the Škoda brand advertisement presented on billboards in Poland in 2014. Billboards displayed on the streets in many cities in Poland drew attention because of their originality, and this originality, as reported in the survey, consisted of using the English word amazing and its phonetic transcription. An error in the form of using an unauthorized English symbol [э] introduced to the amazing word transcription in the Škoda advertisement slogan, was recognized by $95 \%$ of respondents. On the one hand, it is a very good result, because it proves that after the course of phonetics and phonology, students are very familiar with the English phonetic symbols. On the other hand, this question was intended to check the percentage of respondents who do not recognize transcription errors or do not notice the occurrence of transcription in the 
advertisement. As aforementioned, in the first stage of the study, $17.8 \%$ of participants indicated that mainly transcription attracts their attention. This is not a high rate compared to the second option, which was indicated by $57 \%$, and it was a slogan in English. The answers given can be interpreted in two different ways. In the first place, only $17.8 \%$ notice transcription in advertising, and despite being students of English, only a few of them notice errors. In the light of such responses, will the ordinary recipient of this advertisement notice transcription at all? Perhaps not, which may mean that it functions only as a graphic element, to put it differently, in the way predicted by the copywriter. Secondly, as many as $17.8 \%$ of participants in the study noticed transcription and some of them may have considered it to be correct. Thirdly, in the second stage of the study, a large majority of participants noticed transcription and pointed out errors occurring in it admitting at the same time that as students of English they can use this advertisement (41.1\% / 48\%) to their benefit. Admittedly, among the answers such as: "I can learn transcription; I will know how to transcribe the word Szczecin; I didn't know that Polish words can be transcribed using English phonetic symbols", there were statements such as: "I can't read the transcription; I don't know how to pronounce some symbols, for example, $[\mathrm{S}]$ ]", which may indicate that the advertisement might trigger their interest in the transcription.

As to the communicative value of both advertisements, it should be emphasized that the presented advertising slogan and logo in the advertisement of Szczecin and the transcription of the word amazing in the advertisement of the Škoda brand have not been unequivocally assessed by the surveyed group of respondents as effective or ineffective. As a reminder, $48 \%$ of respondents in the second stage of the study responded positively to the statement "This logo fulfills the goal of the city" (in the first stage $44.2 \%$ ), and negatively $52 \%$ (in the first stage $55.8 \%$ ). The remarks expressed in response to the question about the potential recipient of the advertisement of Szczecin highlight the view that it was designed for foreigners and the native speakers of English. Only 14.8\% of them reported that the Poles were the target recipients. Evaluating the communicativeness of the advertisements, at this point, on the basis of the responses it can be assumed that the copywriters designing an advertisement with the use of English words subconsciously acted against the rules of ethics as formulated by the Committee of Advertising Ethics. According to the rules, the advertisements should be designed in the form and in the language understandable to the recipients in the country in which the advertisement is launched. Finally, if the copywriters' purpose was to attract foreigners' attention and help them pronounce the name of the city, and to this end they used the phonetic transcription of Szczecin, the surveyed students did not clearly support this idea. They reported the reverse, namely, that it is highly probable that the foreigners, including native speakers of English, do not know the phonetic symbols, hence, are unable to decode the transcription. 


\section{Conclusions}

As can be seen from the foregoing discussion, the use of the visual aspect in advertising cannot be assessed only from the point of view of a copywriter, who uses various techniques to attract customers' attention, increase viewership or the sales index. When copywriters engage in the definition of communication a visual aspect, which is in the form of phonetic symbols, they should do it in a thoughtful way, in consultation with people having sufficient knowledge in this area because the wrongly presented transcription may serve as a norm provider. However, the idea of using various types of advertising tricks, including language errors in order to advertise products, is gaining popularity because such tricks aid advertising in arousing emotions and interest. Nevertheless, when assessing the effectiveness of advertising with the use of a visual message, one should take into account the level of understanding by the recipients, because "a fragment of a visual message can be understood or not" (Nuckowski as cited in Polak, 2001). As it is clear from the above discussion, this type of advertising (logo) is the message that is mostly understood by the recipient having some knowledge of phonetics.

\section{References}

ASH. 2009. "Szczeczin Floating Garden dla nie-Polaków". Available at: http://szczecin.wyborcza. pl/szczecin/1,34939,6757914,Szczeczin_Floating_Garden_dla_nie_Polakow.html?disableRedirects=true (date of access: 25 August 2014).

Bigaj-Zwonek, B. 2011. "Czerwone zygzaki po przekątnej kartki, czyli o sposobach budowy przekazu w obrazie". In: Polak, R. (ed.). Oblicza komunikowania wizualnego. Kraków-Rzeszów-Zamość: Konsorcjum Akademickie. 99.

Bocock, R. 1993. Consumption. London: Routledge.

Bovée, C.L. and W.F. Arens. 1982. Contemporary advertising. Homewood, Illinois: Richard D. Irwin.

Cook, G. 1992. The discourse of advertising. London: Routledge.

Dziczek-Karlikowska, H. and B. Mikołajewska. 2015. "Computer-assisted awareness raising of L2 phonology: Pronunciation in commercials - a pilot study". In: Turula, A., Mikołajewska, B. and D. Stanulewicz (eds.). Insights into technology enhanced language pedagogy. Gdańsk Studies in Language 4. Frankfurt am Main: Peter Lang GmbH. 145-163.

Ewen, S. 1976. Captains of consciousness: advertising and the social roots of the consumer culture. New York: McGraw-Hill.

Fox, S. 1984. The mirror makers. A history of American advertising and its creators. New York: William Morrow.

Gieszinger, S. 2001. The history of advertising language. Frankfurt am Main: Peter Lang GmbH.

Goddard, A. 1998. The language of advertising. Written texts. London: Routledge.

Herméren, L. 1999. English for sale. A study of the language of advertising. Lund: Lund University Press.

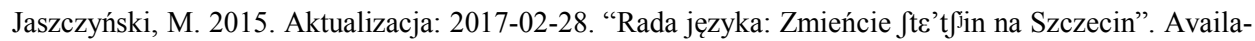
ble at: http://szczecin.naszemiasto.pl/artykul/rada-jezyka-zmiencie-t-t-in-na-szczecin,3051506,artgal, t,id,tm.html (date of access: 30 August 2018). 
Jones, D. [1917]/2006. Cambridge English pronouncing dictionary. Cambridge: Cambridge University Press.

Leech, G. 1966. English in advertising. A linguistic study of advertising in Great Britain. London: Longmans.

Loughran, J.J. 1996. Developing reflective practice. London, Washington D.C.: Falmer Press.

Lynch, D. 1980. "Film: The Elephant Man". In: Wolny-Zmorzyński, K. at al. (eds.). Komunikacja wizualna w reklamie, public relations $i$ w prawie. Warszawa: Wydawnictwo Poltext. 99.

Myers, G. 1994. Words in ads. London: Edward Arnold.

Nuckowski, J. 2011. "O komunikacji wizualnej”. In: Polak, R. (ed.) Oblicza komunikowania wizualnego. Kraków-Rzeszów-Zamość: Konsorcjum Akademickie. 44-46.

Oficjalna strona miasta Szczecin w języku angielskim. Szczecin Floating Garden 2050. Available at: http://www.szczecin.eu/en/marka/brand_strategy (date of access: 2 September 2018).

Polak, R. (ed.). 2011. Oblicza komunikowania wizualnego. Kraków-Rzeszów-Zamość: Konsorcjum Akademickie.

Rabenda, M. 2015. "Na ile już jesteśmy Floating Garden? Remanent na siedmiolecie wprowadzenia marki". Available at: http://szczecin.wyborcza.pl/szczecin/1,34939,17927811,Na_ile_juz_jestesmy_ Floating_Garden_Remanent_na_siedmiolecie.html (date of access: 14 August 2018).

Rada Języka Polskiego. Available at: http://www.rjp.pan.pl/index.php?option=com_content\&view=article $\& \mathrm{id}=212 \&$ catid=36\&Itemid=73. (date of access: 30 August 2018).

Richards, J.C. and C. Lockhart. 1996. Reflective teaching in second language classrooms. Cambridge: Cambridge University Press.

Russel, T. 1920. Commercial advertising. Six lectures at the London School of Economics and Political Science (University of London). Lent term 1919. London: G.P. Putnam's Sons.

Sampson, H. [1874] 2015. History of advertising from the earliest times: illustrated by anecdotes, curious specimens and bibliographical notes. Reprint by BiblioLife.

Sauer, H. 1998. "Englische Werbesprache". Wissenschaftliche Zeitschrift der Technischen Universitat Dresden 47. 87-96.

Schudson, M. 1993. Advertising, the uneasy persuasion. Its dubious impact on American society. $2^{\text {nd }} \mathrm{ed}$. London: Routledge.

Scott W.D. [1903] 2015. The theory of advertising. A simple exposition of the principles of psychology in their relation to successful advertising. Reprint by BiblioLife DBA of Biblio Bazaar.

Škoda Octavia 1.4 Ambition. Available at: https://www.google.pl/search?q=Škoda+reklama+na+billboar dach\&tbm $=$ isch\&tbo=u\&source $=$ univ\&sa $=X \&$ ei $=$ S337U61 eqdXhBMH0gZgI\&ved=0CEcQ7Ak\&biw $=1024 \&$ bih $=498 \#$ facrc $=\_$\&imgdii $=\_\& i m g r c=m Z Q Z n 8 a k Q h s F t M \% 253 \mathrm{~A} \% 3 \mathrm{BXIBmsxVGb0RD4M \%}$ 3Bhttp\%253A\%252F\%252Feventmanagernews.pl\%252Fwp content\%252Fuploads\%252F13-case-stu dy-pierwszy-w-polsce-mapping-na-muralu-featured image.jpg\%3Bhttp $\% 253 \mathrm{~A} \% 252 \mathrm{~F} \% 252 \mathrm{Feventma}$ nagernews.pl\%252Fpierwszy-w-polsce-mapping-na-muralu\%252F\%3B520\%3B400 (date of access: 26 August 2014).

Szczęsna, E. 2001. Poetyka reklamy. Warszawa: Wydawnictwo Naukowe PWN.

Tanaka, K. 1994. Advertising language. A pragmatic approach to advertisements in Britain and Japan. Abingdon: Routledge.

Turula, A., Mikołajewska, B. and D. Stanulewicz (eds.). 2015. Insights into technology enhanced language pedagogy. Gdańsk Studies in Language 4. Frankfurt am Main: Peter Lang GmbH.

Wolny-Zmorzyński, K., Furman, W., Snopek, J. and K. Groń (eds.). Komunikacja wizualna w reklamie, public relations $i$ w prawie. Warszawa: Wydawnictwo Poltext.

Vestergaard, T. and K. Schrøder. 1985. The language of advertising. Oxford: Basil Blackwell. 